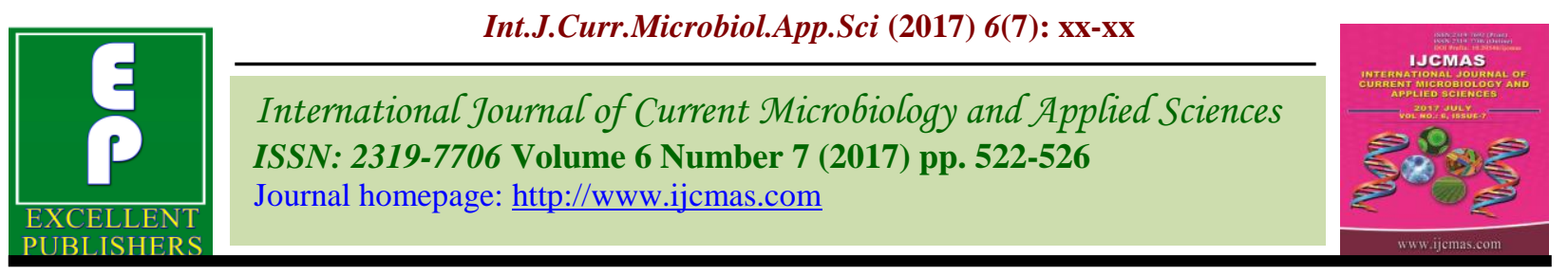

Original Research Article

https://doi.org/10.20546/ijcmas.2017.607.063

\title{
Heterosis in Cowpea (Vigna unguiculata L. Walp) for Selected Traits
}

\author{
P.S. Sarath* and T. Reshma \\ Kerala Agricultural University, Vellanikkara, Thrissur - 680656, Kerala, India \\ *Corresponding author
}

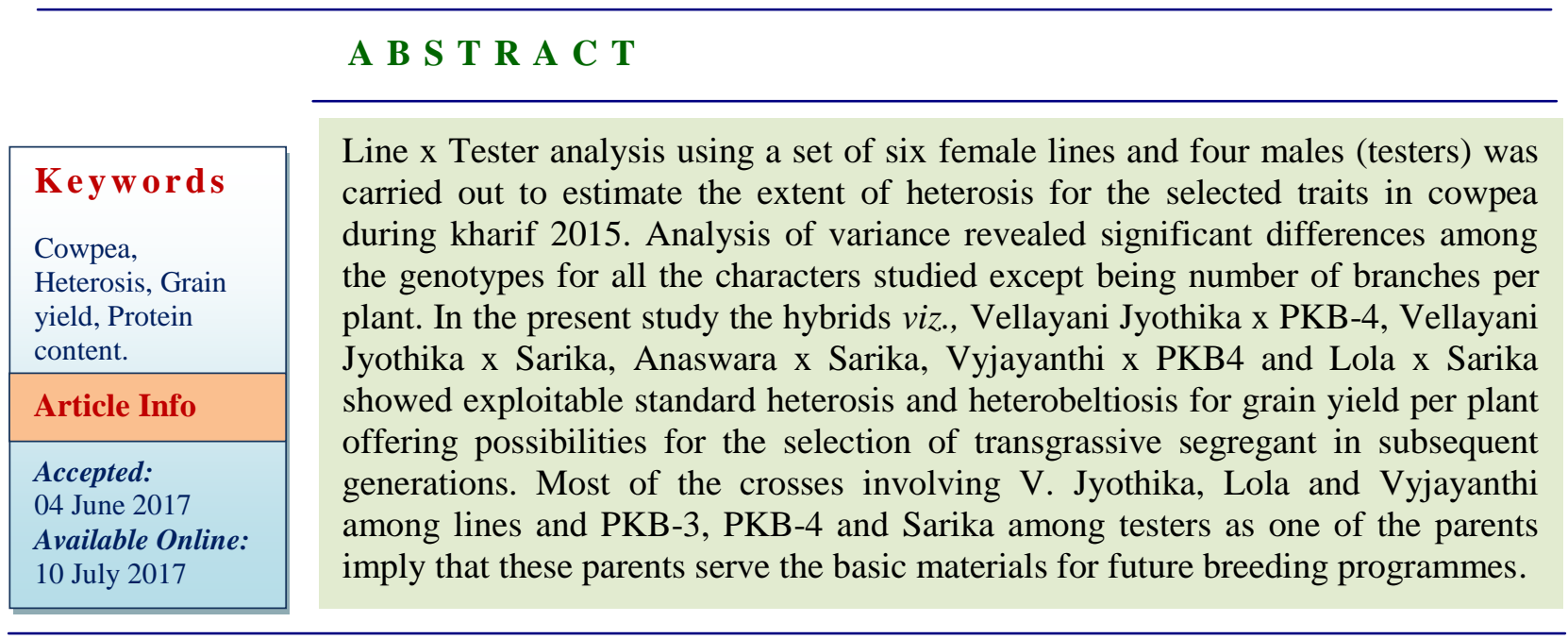

\section{Introduction}

Heterosis is the genetical phenomenon referred to denote the expression of increased vigour. Vigour of hybrids is estimated over mid parent, better parent and standard parent. Utilization of heterosis is important for maximization of yield as well as seed protein content in cowpea.

Estimation of heterosis over better parent may be useful in identifying true heterotic cross combinations but these crosses can be of immense practical value if they show superiority over better parent or best variety of the area. The overall effect of plant breeding on genetic diversity has been a long standing concern in the evolutionary biology of crop plants (Simmonds, 1962). Genetic erosion has been dramatic for many cultivated species. In a self-pollinating crop like cowpea, variability is often created through hybridization between carefully chosen parents. Therefore, the present investigation was carried out to collect information on heterosis for the selected traits in cowpea.

\section{Materials and Methods}

The ten parental genotypes were crossed in line $\mathrm{x}$ tester mating design (6 lines and 4 testers), to obtain 24 F1 hybrids (Table 1). The emasculation and pollination were done as per method proposed by Krishnaswamy et al., (1945). Staggered sowing of each variety was done at weekly intervals to ensure synchronized flowering between male and female plants and pollen availability for 
hybridization. The experiment consisting of 34 treatments comprising ten parents and 24 F1s was laid out in a randomized block design with two replications during summer 2015. The recommended agronomic practices and plant protection measures were adopted for raising a good crop. Observations were recorded on randomly selected ten plants chosen at random in each entry for 10 quantitative traits viz., plant height $(\mathrm{cm})$, number of branches per plant, days to first flowering, days to first harvest, days to last harvest, number of pods per plant, number of seeds per pod, length of pod, pod weight, test weight, grain yield and protein content. The data were analysed to compute heterosis (\%) over better parent (BP) and standard check $(\mathrm{SH})$ values.

\section{Results and Discussion}

The analysis of variance (Table 2) revealed that there existed significant difference among the genotypes for most of the characters studied with exception of number of branches. This indicated that there was sufficient variability among the genotypes as well as parents and F1s for the characters under study and thus there has been a chance for the improvement through appropriate breeding methods. The mean squares due to parents and hybrids indicated much variation among them. This implies the existence of considerable variability contributed by the genetic causes. ANOVA for combining ability show that lines vary for plant height, days to flowering, days to first harvest, days to last harvest, number of pods per plant, seeds per pod, grain yield per plant and protein content. Testers did not vary for these traits. Hybrids vary for plant height, days to flowering, days to first harvest, days to last harvest, number of pods per plant, length of pod, test weight, seeds per pod, grain yield per plant and protein content. The line $\mathrm{x}$ tester interaction significant for number of pods per plant, length of pods, pod weight, seeds per pod, test weight, grain yield per plant and protein content.

For plant height 13 hybrids registered significant negative heterobeltiosis and 12 hybrids exhibited significant negative standard heterosis. Hybrids in which Bhagyalakshmi was the female parent exhibited high magnitude of heterobeltiosis and standard heterosis in negative direction. The Hybrid Bhagyalakshmi x Sharika recorded highest negative standard heterosis. The varied degree of heterosis for plant height in cowpea has been described by Ushakumari et al., (2010) and Sharma et al., (2013). Regarding branches per plant, the hybrid Vellayani Jyothika fg $x$ PKB-4 showed highest value for heterobeltiosis. Whereas maximum value for standard heterosis registered by the hybrid Kanakamony x PKB4. Hybrids in which Vellayani Jyothika as the female parent exhibited high significant positive heterosis for number of branches per plant irrespective of the testers used.

Table.1 Designation of genotypes resulting from line $\mathrm{x}$ tester mating design

\begin{tabular}{|l|l|l|l|l|}
\hline Line/ Tester & AV-5 (T1) & PKB-3 (T2) & PKB-4 (T3) & Sharika (T4) \\
\hline V. Jyothika (L1) & H1 & H2 & H3 & H4 \\
\hline Bhagyalakshmi (L2) & H5 & H6 & H7 & H8 \\
\hline Anaswara (L3) & H9 & H10 & H11 & H12 \\
\hline Vyjayanthi (L4) & H13 & H14 & H15 & H16 \\
\hline Lola (L5) & H17 & H18 & H19 & H20 \\
\hline Kanakamony (L6) & H21 & H22 & H23 & H24 \\
\hline
\end{tabular}


Table.2 Analysis of variance for $1 \mathrm{x} t$ analysis for various traits

\begin{tabular}{|c|c|c|c|c|c|c|}
\hline $\begin{array}{l}\text { Source of } \\
\text { variation }\end{array}$ & $\begin{array}{l}\text { Treatments } \\
\text { (genotypes) }\end{array}$ & Hybrids & Lines & Testers & $\mathrm{L} \times \mathrm{T}$ & Error \\
\hline $\mathrm{df}$ & 33 & 23 & 5 & 3 & 15 & 33 \\
\hline Plant height & $13710.38 * *$ & $974.13 * *$ & 7150.15 & 315.46 & 196.45 & 96.55 \\
\hline No. of branches & 4.58 & 11.21 & 1.86 & 17.05 & 9.05 & 5.76 \\
\hline Days to flowering & $157.59 * *$ & $565.17 * *$ & $3281.23 * *$ & 105.26 & 55.37 & 62.21 \\
\hline $\begin{array}{c}\text { Days to first } \\
\text { harvest }\end{array}$ & $215.96^{* *}$ & $1052.31 * *$ & $4450.14 * *$ & 190.14 & 95.14 & 85.11 \\
\hline $\begin{array}{c}\text { Days to last } \\
\text { harvest }\end{array}$ & $365.76^{* *}$ & $1374.21 * *$ & $5314.14 * *$ & 224.16 & 106.27 & 100.31 \\
\hline $\begin{array}{c}\text { No. of pods per } \\
\text { plant }\end{array}$ & $717.26^{* *}$ & $600.11 * *$ & $3210.24 * *$ & 60.20 & $468.30 * *$ & 53.15 \\
\hline Length of pods & $549.83 * *$ & $16.56 * *$ & 3.91 & 1.42 & $27.01 * *$ & 5.76 \\
\hline Pod weight & $131.50 * *$ & 9.24 & 1.17 & 8.12 & $12.01 * *$ & 5.05 \\
\hline Seeds per pod & $13.96 * *$ & $10.22 * *$ & $72.21 * *$ & 1.01 & $2.72 * *$ & 0.45 \\
\hline Test weight & $25.96 * *$ & $38.25 * *$ & $78.61 * *$ & 22.51 & $35.23 * *$ & 4.42 \\
\hline $\begin{array}{c}\text { Grain yield per } \\
\text { plant }\end{array}$ & $5715.41 * *$ & $85.21 * *$ & $189.79 * *$ & 50.76 & $81.53 * *$ & 15.50 \\
\hline Protein content & $8.42 * *$ & $7.34 * *$ & $34.31 * *$ & 3.98 & $3.83 * *$ & 0.11 \\
\hline
\end{tabular}

Table.3 Range of heterosis, best crosses and number of crosses showing significant heterobeltiosis $(\mathrm{HB})$ and standard heterosis $(\mathrm{SH})$ for 12 traits in cowpea

\begin{tabular}{|c|c|c|c|c|c|c|}
\hline \multirow[t]{2}{*}{ Character } & \multicolumn{2}{|c|}{ Range of heterosis } & \multicolumn{2}{|c|}{$\begin{array}{l}\text { No of crosses showing } \\
\text { significant and desirable } \\
\text { heterosis }\end{array}$} & \multicolumn{2}{|l|}{ Best crosses } \\
\hline & $\mathrm{HB}$ & $\mathrm{SH}$ & HB & $\mathrm{SH}$ & HB & $\mathrm{SH}$ \\
\hline Plant height & $\begin{array}{l}-166.18 \text { to } \\
52.66\end{array}$ & $\begin{array}{l}-53.27 \\
24.60\end{array}$ & 13 & 12 & $\begin{array}{l}\text { Bhagyalakshmi } \mathrm{x} \\
\text { Sarika }(-166.18 \%)\end{array}$ & $\begin{array}{l}\text { Anaswara } \times \text { AV }-5 \\
(-53.27 \%)\end{array}$ \\
\hline $\begin{array}{l}\text { No. of } \\
\text { branches }\end{array}$ & $\begin{array}{ll}-36.27 & \text { to } \\
37.41 & \end{array}$ & $\begin{array}{l}-26.15 \\
48.12\end{array}$ & 12 & 10 & $\begin{array}{l}\text { V. Jyothika x PKB- } \\
4(37.41 \%)\end{array}$ & $\begin{array}{l}\text { Kanakamony } \quad \mathrm{X} \\
\text { PKB-4 }(48.12 \%)\end{array}$ \\
\hline $\begin{array}{l}\text { Days to } \\
\text { flowering }\end{array}$ & $\begin{array}{l}-25.87 \text { to } \\
41.10\end{array}$ & $\begin{array}{l}-24.52 \\
19.60\end{array}$ & 9 & 5 & $\begin{array}{l}\text { Anaswara x PKB-3 } \\
(-25.87 \%)\end{array}$ & $\begin{array}{l}\text { Anaswara x PKB- } \\
3(-24.52 \%)\end{array}$ \\
\hline $\begin{array}{l}\text { Days to first } \\
\text { harvest }\end{array}$ & $\begin{array}{l}-25.90 \text { to } \\
25.68\end{array}$ & $\begin{array}{l}-28.69 \\
21.25\end{array}$ & 9 & 3 & $\begin{array}{ll}\text { Bhagyalakshmi } & \mathrm{x} \\
\text { Sarika }(-25.90 \%) & \end{array}$ & $\begin{array}{l}\text { Lola x AV-5 (- } \\
28.69 \%)\end{array}$ \\
\hline $\begin{array}{c}\text { Days to last } \\
\text { harvest }\end{array}$ & $\begin{array}{l}-15.55 \text { to } \\
26.99\end{array}$ & $\begin{array}{l}-9.66 \\
18.00\end{array}$ & 5 & 2 & $\begin{array}{lr}\text { Lola } \quad x & \text { PKB-4 } \\
(26.99 \%) & \end{array}$ & $\begin{array}{l}\text { Bhagyalakshmi } \quad \mathrm{x} \\
\text { Sarika }(18.00 \%)\end{array}$ \\
\hline $\begin{array}{l}\text { No. of pods } \\
\text { per plant }\end{array}$ & $\begin{array}{ll}-32.14 & \text { to } \\
145.22 & \end{array}$ & $\begin{array}{l}-31.99 \\
62.78\end{array}$ & 15 & 15 & $\begin{array}{l}\text { Kanakamony } \mathrm{x} \\
\text { Sarika }(145.22 \%)\end{array}$ & $\begin{array}{l}\text { Anaswara x PKB- } \\
3(62.78 \%)\end{array}$ \\
\hline Length of pods & $\begin{array}{l}-55.21 \text { to } \\
18.67\end{array}$ & $\begin{array}{ll}-66.09 & \text { to } \\
196.65 & \end{array}$ & 2 & 6 & $\begin{array}{l}\text { V. Jyothika x PKB- } \\
4(18.67 \%)\end{array}$ & 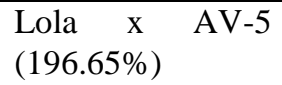 \\
\hline Pod weight & $\begin{array}{ll}-72.07 & \text { to } \\
24.35 & \end{array}$ & $\begin{array}{l}-10.58 \\
210.26\end{array}$ & 7 & 23 & $\begin{array}{ll}\text { V. Jyothika } & \mathrm{x} \\
\text { Sarika }(24.35 \%) & \end{array}$ & $\begin{array}{l}\text { V. Jyothika x } \\
\text { Sarika }(210.26 \%)\end{array}$ \\
\hline Seeds per pod & $\begin{array}{ll}-33.93 & \text { to } \\
18.15 & \\
\end{array}$ & $\begin{array}{l}-19.09 \\
19.60 \\
\end{array}$ & 4 & 4 & $\begin{array}{l}\text { V. Jyothika x PKB- } \\
4(18.15 \%)\end{array}$ & $\begin{array}{lr}\text { Lola X } & \text { Sarika } \\
(19.60 \%) & \\
\end{array}$ \\
\hline Test weight & $\begin{array}{l}-57.26 \text { to } \\
22.77\end{array}$ & $\begin{array}{l}-79.68 \\
192.74 \\
\end{array}$ & 7 & 20 & $\begin{array}{l}\text { Anaswara x Sarika } \\
(22.77 \%)\end{array}$ & $\begin{array}{l}\text { Bhagyalakshmi x } \\
\text { AV-5 (192.74\%) }\end{array}$ \\
\hline $\begin{array}{c}\text { Grain yield per } \\
\text { plant }\end{array}$ & $\begin{array}{ll}-89.00 & \text { to } \\
58.84 & \\
\end{array}$ & $\begin{array}{l}-26.95 \\
89.69 \\
\end{array}$ & 6 & 10 & $\begin{array}{ll}\text { Kanakamony } & \mathrm{X} \\
\text { Sarika }(58.84 \%) & \\
\end{array}$ & $\begin{array}{l}\text { Bhagyalakshmi } \mathrm{x} \\
\text { Sarika }(89.69 \%)\end{array}$ \\
\hline Protein content & $\begin{array}{ll}-15.47 & \text { to } \\
12.10 & \end{array}$ & $\begin{array}{l}-7.68 \\
22.53\end{array}$ & 12 & 17 & $\begin{array}{ll}\text { Kanakamony } & \mathrm{x} \\
\text { AV-5 }(12.10 \%) & \end{array}$ & $\begin{array}{l}\text { Kanakamony } \quad \mathrm{X} \\
\text { PKB-4 }(22.53 \%)\end{array}$ \\
\hline
\end{tabular}


With regard to days to flowering negative heterosis will be useful for the breeder to develop vigorous early maturing genotypes. Among 24 hybrids only four hybrids exhibited significant negative, heterobeltiosis and standard heterosis. Hybrids involving Bhagyalakshmi as female parent registered high magnitude of heterobeltiosis and standard heterosis in negative direction. The standard heterosis was highest in negative direction in cross Anaswara x PKB-3. Similar to days to flowering, in case of days to first harvest, hybrids in which Bhagyalakshmi as female parent exhibited high significant negative value for heterobeltiosis and standard heterosis. Seven hybrids recorded significant heterobeltiosis while four hybrids registered significant standard heterosis. In the case of pod yield per plant the highest heterobeltiosis and standard heterosis were exhibited by the crosses Anaswara x PKB-3 and Kanakamony x Sarika respectively.

For the same trait 15 hybrids showed significant and positive heterobeltiosis and 14 crosses showed significant and positive standard heterosis. Patel et al., (2007) and Selvakumar et al., (2014) reported three type of heterosis in pods per plant for length of pod V.Jyothika x PKB-4 and Lola x AV-5 were emerged as best heterobeltiotic and standard heterotic crosses respectively. In addition to this 2 hybrids showed significant heterobeltiosis and 6 hybrids showed standard heterosis for this trait.

With regard to pod weight the hybrid V.Jyothika x Sarika exhibited highest positive heterobeltiosis and standard heterosis. 7 hybrids exhibited significant positive heterobeltiosis and all the crosses except Kanakamony x Sarika exhibited significant and positive standard heterosis. For seeds per pod 4 crosses over better parent and 5 crosses over standard check depicted significant and positive heterosis. For test weight 7 hybrids showed significant and positive heterobeltiosis and 20 crosses showed significant standard heterosis. For grain yield per plant 6 crosses expressed significant positive heterobeltiosis and 10 hybrids exhibited significant positive standard heterosis. The crosses Vellayni Jyothika $\mathrm{x}$ PKB-4, Vellayani Jyothika X Sarika, Anaswara x Sarika, Vyjayanthi x PKB4 and Lola $x$ Sarika exhibited significant positive heterobeltiosis and standard heterosis for grain yield per plant. These could be exploited for its yield potential to obtain desirable segregants in future breeding programme. With regard to protein content 12 crosses showed significant and positive heterobeltiosis and 17 crosses showed significant and positive standard heterosis. Hybrids in which female parents were Bhagyalakshmi, Anaswara and Kanakamony registered positive significant heterobeltiosis and standard heterosis for protein content. Inuwa et al., (2013) reported three type of heterosis for protein content in cowpea (Table $3)$.

Thus from the present study it can be conclude that most of the hybrids exhibiting significant heterosis for different traits over better parent / standard check. V.Jyothika, Lola and Vyjayanthi among lines and PKB-3, PKB-4 and Sarika among testers as one of the parents implies that these parents provide the basic materials for breeding programme for further improvement in yield and yield contributing traits in cowpea. The crosses V.Jyothika x PKB-4, V.Jyothika x Sarika, Anaswara $x$ Sarika and Lola $x$ Sarika exhibited significant standard heterosis and heterobeltiosis for grain yield per plant and other yield contributing traits. Thus these crosses may offer for the selection of transgrassive segregant in subsequent generation owing to self-pollinated nature of cowpea, heterosis breeding may not be rewarding like in the case of a cross 
pollinated crop.

\section{References}

Inuwa, A. H., Muhammed, S. G., and Mustapha, Y. Genetic variability and heritability of some selected cowpea lines (V. unguiculata). World J. Agric. Sci. 25: 251-256.

Krishnaswamy, N., Nambiar, K. K., and Mariakulandai, A. 1945. Studies in cowpea (V. unguiculata). Madras Agric. J. 33: 145-160.

Patel, B. N., Desai, R.T., and Chaudhari, K.

N. 2007. Diallele analysis for seed yield in cowpea ( $V$. unguiculata). Res. Crops 14: 135-139.

Selvakumar, G., Anandakumar, C. R., Chinniah, C., and Ushakumari, C. 2014. Combining ability analysis in the inter sub specific crosses of Vigna unguiculata and yard long bean (Vigna sesquipedalis). Electr. J. Plant Breed. 5:187-191.

Sharma, D., Mehta, N., Singh, J., and Guptha, C. R. 2013. Genetic study for some pod characters in vegetable cowpea $(V$. unguiculata). Electr. J. Plant Breed. 5: 21-23.

Simmonds, N. W. (1962). Variability in crop plants, its use and conservation. Biol. Rev. 37: 314-18.

Ushakumari, R., Vairam, N., Anandakumar, C., and Malini, N. 2010. Studies on hybrid vigour and combining ability for seed yield and contributing characters in cowpea (V. unguiculata). Electr. $J$. Plant Breed. 1: 940-947.

\section{How to cite this article:}

Sarath, P.S. and Reshma, T. 2017. Heterosis in Cowpea (Vigna unguiculata L. Walp) for Selected Traits. Int.J.Curr.Microbiol.App.Sci. 6(7): 522-526. doi: https://doi.org/10.20546/ijcmas.2017.607.063 